\title{
E-SERVICES IN PUBLIC ADMINISTRATION ON THE BASIS OF THE POLISH SOCIAL INSURANCE INSTITUTION (ZUS)
}

\author{
E-USŁUGI W ADMINISTRACJI PUBLICZNEJ \\ NA PRZYKŁADZIE ZAKŁADU UBEZPIECZEŃ SPOŁECZNYCH
}

https://doi.org/10.34739/zn.2021.55.03

\author{
Anna Owczarczyk ${ }^{1}$, Joanna Lazurek ${ }^{2}$ \\ ${ }^{1}$ Poland, Siedlce University of Natural Sciences and Humanities, Faculty of Social Sciences \\ anna.owczarczyk@uph.edu.pl, ORCID: 0000-0003-1363-2296 \\ ${ }^{2}$ Poland, Siedlce University of Natural Sciences and Humanities, Faculty of Social Sciences
}

JEL Classification Codes: H83

\begin{abstract}
The term e-services refers to such services that are delivered over the Internet and their rendition is frequently automated and remote. Apart from the Internet, an e-service may also be provided by means of mobile devices or television. The wider and wider range of e-services is offered by institutions from the public administration sector, striving to anticipate their client's expectations (especially those of the younger generation) and using the ongoing digitisation process. This study aims at presenting the role and opinions of e-service in one of the social insurance institutions, i.e. Social Insurance Institution (ZUS) where numerous electronic tools have been implemented facilitating work and enabling clients to make contact, get information, send and receive documents. All these efforts are made so as to increase accessibility for prospective and current clients as well as to make the institution's operations more efficient. To achieve this, the following research methods were used: a critical analysis of the literature, an analysis of statistical data, an analysis of survey results (conducted by ZUS), and a survey questionnaire (own research).
\end{abstract}

Key words: e-services, public administration, social insurance

Streszczenie: Mianem e-usług określa się takie usługi, których świadczenie odbywa się za pośrednictwem Internetu, często bywa ono zautomatyzowane i zdalne. Oprócz Internetu e-usługę można świadczyć także za pośrednictwem urządzeń mobilnych czy telewizji. Coraz szerszy wachlarz e-usług oferują instytucje ze sfery administracji publicznej, wychodząc naprzeciw oczekiwaniom klientów (zwłaszcza młodszego pokolenia) oraz wykorzystując rozwój cyfryzacji. Celem artykułu jest przedstawienie roli i opinii e-usługi w Zakładzie Ubezpieczeń Społecznych (ZUS), gdzie zaimplementowano liczne elektroniczne narzędzia usprawniające pracę oraz umożliwiające nawiązanie kontaktu, uzyskanie informacji, wysyłanie i odbieranie dokumentów. Wszystko to w celu zwiększenia dostępności dla potencjalnych i obecnych klientów, a także dla efektywniejszej pracy. Dla realizacji celu wykorzystano następujące metody badawcze: krytyczną analizę literatury, analizę danych statystycznych, analizę wyników ankiety (przeprowadzonej przez ZUS) oraz ankiety stanowiącej badania własne.

Słowa kluczowe: e-usługi, administracja publiczna, ubezpieczenia społeczne

\section{Introduction - theoretical background}

The term e-services refers to such services that are delivered over the Internet, their supply is automated (they may require minimal human intervention) and remote. Apart from the Internet, an e-service may be provided by means of mobile devices or satellite and digital television (Batko, 2013, p. 54). Chun Hai argues that e-services are services on the Internet where it is possible to make a purchase and sale transaction, unlike traditional websites, where only descriptive information is available. Similar Zeithaml and Bitner defined e-service as web services delivered through the Internet (Kvasnicova et all, 2016). According to R. Wolny (2013, p. 16), an e-service is a form of providing services using the Internet, which includes, in particular, a presentation of a service, a method to order the service, a payment for the service and access to the service via the Internet, apart from certain exceptional situations where the service is used in the real (non-virtual) world. Flis 
(2009, p. 11) in turn, states that the e-service offers a client possibly broad independence; however, it does not require both parties to be present at the same place at the same time. Another characteristic feature of e-services, according to Council Implementing Regulation (EU) No. 282/2011 of 15 March 2011 is the fact that they are impossible to ensure in the absence of information technology (Kowalewski, 2019, p.131). According to Lindgren and Jansson, the term e-service contains two parts: the e- and the service. These two parts can be understood as elements that represent two different things. The ' $e$ ' represents the fact that something is done 'electronically' and can thus be linked to an electronic artifact. The 'service' represents something intangible - a process in which value is created for someone. Hence, the e-service concept can be explored both from (1) an electronic artifact (technology) perspective, and (2) a service perspective. When considering the organizational context in which the e-service is used, yet another perspective is added. This perspective highlights the ownership or availability of the artifact or service; a perspective in which attention is directed towards exploring potential implications based on whether the e-service is (3) public or private (Lindgren et al., 2013, pp 163-172).

It seems to be impossible to set out clear boundaries separating e-services from internet options that are not e-services due to the nature of the environment in which the service is created and developed (Batko, 2013, p. 56). Thus, it is often difficult to clearly state whether a given online activity constitutes or not an e-service. An e-service is identified and interpreted as a service that meets the following criteria:

- its rendition is partly or entirely automated with the use of information technology,

- it is delivered on the Internet or over the Internet,

- it is tailor-made (customized) for the recipient,

- the parties to the service rendered are in different locations (a remote service) (Dąbrowska et al., 2009, p.v41).

What makes an e-service different from a t-service, i.e. a service provided in a traditional manner, is the lack of human intervention on the other end and remote rendition of the service. E-services should be delivered by means of an information system, e.g. an online application, an internet service, and provided on demand of a service recipient (at every time and in various forms) (Śliwiński, 2008, p. 33-35).

While analysing e-services, particular attention should be paid to the areas of their implementation. We may observe a dynamic development of e-services in the area of communication, administration. commerce, banking, healthcare, finances, education, tourism, or culture (Batko, 2013, pp. 65-66). The implementation of communication and information technology in these areas is referred to accordingly as:

- e-communication, or communication using internet channels, for example internet communicators, forums, or video call services (e.g. Skype),

- e-administration, or the process of continuous improvement of administration services quality using the Internet and modern means of communication,

- e-commerce, or processes of buying and selling products and services, i.e. concluding trade transactions over the Internet,

- e-banking (online banking), online banking services including financial and advisory services, handling bank accounts and credit cards,

- e-healthcare, which refers to using information and communication technology in preventive healthcare, diagnostics, treatment, control, and implementing a healthy lifestyle,

- e-finance, or services referring mostly to the access to current financial information, handling own financial portfolios, purchasing financial and insurance services or investment advice,

- e-working (teleworking), or remote work provided outside the company premises by means of the Internet connection or other devices: a telephone, a fax machine, or a computer, which allow remote working,

- e-education, or a method of remote education using the Internet, intranet, CD-rom, satellite broadcast, video call applications, television or radio,

- e-tourism, or using the Internet to running tourist activities where the Internet is used to promote and trade a tourist product (a service),

- e-culture, or the process of making the world heritage available via modern broadcasting channels ranging from television to the Internet.

Following the current trend, and in response to the needs and expectations of citizens, enterprises, and non-governmental organisations, we have observed a significant development of services provided by electronic means by the public administration sector. It is widely believed that e-administration and e-government play a crucial role in reforming the quality of public service. In Western countries, e-government was already started in the 1990s, nonetheless, developing countries have just begun implementing this system (Sofiarti Anggunia). What is more, the primary reason for the creation and development of 
electronic public administration was to increase the efficiency of institutional operation first and consequently of governance, as a result (Radu, et al. 2014, pp.185-210).

E-administration is a system combining organisational innovation and information and communication technology advances so as to perform basic functions of the public sector in the constantly and dynamically changing social and economic environment (Jastrzębska, 2018, p.124).

With reference to the public administration, we may single out the following levels of application of electronic services:

- the information level - public administration information is made available to users by means of internet portals, without providing the possibility to initiate and handle problems using electronic services,

- the unilateral interaction level - users communicate electronically with administration, e.g. downloading forms from administration units websites, without providing the possibility to handle problems electronically,

- the bilateral interaction level - e.g. the form is accessible to the user online which makes it possible to initiate the case electronically by completing the form and sending the document by electronic means of communication to the administration unit,

- the transactional level - enabling the user to handle electronically an issue in the public administration sector which means the issue is reported to the administration, a response is obtained, and a payment is made,

- the personalisation level - which means that the issue is handled electronically and the service, regarding issuing various administrative decisions for the benefit of the user, is personalised (Kowalewski, 2019, pp. 83-85).

We should bear in mind the fact that electronic administration does not only include citizen's communication with the office but it also comprises transferring data between authorities and within the office to reduce the strain on the citizen of multiple submission of information and statements.

Electronically, the concept of one window limits citizen interactions to one body which gathers and acquires from other authorities and from its own departments the data necessary to handle the matter, and after resolving the matter it transfers information in this scope to appropriate bodies (Sibiga, 2006, pp. 94-95).

The main features of e-administration include (Agusti, 2011):

- transparency, or ensuring the consistency of received and sent messages;

- identification of responsibility for truthfulness and authenticity of the information, thus the ability to instantly identify the author and source of information, if needed;

- interoperability, or the ability to interact so as to ensure users' mutual access to services rendered in these institutions;

- neutrality, reflected in the lack of subjectivity of the service or of the attitude to the matter handled;

- security, understood as the ability of devices and the communication network to encode information, prevent its interception or undesirable modification;

- accessibility, or making it available to the user to receive a requested service within specified scope and on specified conditions;

- usability, referred to as efficiency in use and user satisfaction with the level of provided services. The development of e-services is directly affected mostly by changes occurring in society (Fleszer, 2014, pp. 125-126). According to Holgersson, Karlsson, knowledge of citizens' needs and skills is seen as essential for successful development of public e-services (Holgersson et al., 2014).

It is worth mentioning that public organisations in Poland are obliged by law to develop e-administration (Jastrzębska, 2014, pp.144-148). Since 2014 Electronic Inbox has been used for communication between authorities, entrepreneurs and citizens, the introduction of this inbox is aimed at eliminating from legal regulations of such terms as "available for examination", "in writing", "certified copy", "in-person" for the benefit of equivalent electronic document drivers (Wojsyk, 2014). Using a secure electronic signature or EPUAP, a trusted profile, is equivalent to a handwritten signature.

The public sector is most often associated with local government and central institutions, yet it also comprises several other organisations, which owing to their financial links pertain to the public sphere. These include among others employment offices, tax offices, or social insurance institutions. All of them use ICT facilities and applications, aiming at streamlining the operations and customer service.

This study presents the case of e-administration in one of the social insurance institutions, i.e. the Social Insurance Institution (ZUS), where multiple electronic tools have been implemented which facilitate the institution's work and allow clients to make contact, acquire information, send and receive documents. All these efforts are made so as to increase accessibility for prospective and current clients as well as to make the institution's operations more efficient. 


\section{Method and research - e-services at ZUS}

So as to make an attempt at assessing the effect of the development of electronic platforms made available to the Polish Social Insurance Institution on the workings of the social insurance system, both on the part of ZUS and on the part of clients, secondary research was used (available at www.zus.pl) as well as surveys were conducted among persons using ZUS services. Due to the epidemic situation, it was decided that the safest way to examine the opinions of the clients would be a survey published on one of the social media portals, where the group comprises 14,006 members.

So as to assess the effect of electronic solutions on the efficiency of operations of the social insurance system in 2016-2019 the following indicators were used and interpreted:

- the number of clients who visited the client service room each year,

- the number of clients served by the Call Centre each year,

- social insurance contributions paid each year.

To specify the level of knowledge and application of electronic services offered by ZUS, research was also conducted among the institution's clients. A survey form used included the following questions:

1) Have you noticed any development of ZUS in terms of electronic services in the last 4 years?

2) What digital facilities of ZUS have you come in contact with? (multiple answers could be indicated)

3) Are you willing to use electronic options to gain knowledge, make contact and resolve an issue made available by ZUS or do you prefer to visit a ZUS branch every time you need to resolve an issue or dispel doubts?

4) Do you think that owing to e-services offered by ZUS you may be served and/or obtain necessary information in a faster and easier manner?

170 persons participated in the research, of which: $36 \%$ were persons aged $18-25,35 \%$ - those aged $26-35,16 \%$ - those aged $36-45,8 \%$ - those aged 46-55 and 5\% - those above 55. While analysing respondents' educational background, 74\% were persons with tertiary education, 25\% declared secondary education, and $1 \%$ were persons with primary education.

The below section of the article contains three main parts:

1) Description of e-services used by ZUS and its clients,

2) The impact of electronic solutions on the efficiency of the social insurance system,

3) The degree of awareness and use of electronic services by ZUS clients.
The Polish social security system is operated by several leading public institutions, one of which is the Social Insurance Institution (ZUS), which is responsible for the funding of social benefits. Due to the nature of its operations (money collection, recording, and distribution) it owns an enormous database (300 TB of data, i.e. the amount of data that would need 400,000 CDs to be stored) which it secures but also makes available to other institutions, which need these data, on strictly specified conditions. It transfers electronically information to open pension funds, tax offices, and the National Health Fund. As a result of digital development and of transferring most of the transaction to the net, the Institution is becoming a more and more efficient e-office, which uses new technologies to contact both its clients and institutions it collaborates with (Raport Roczny ZUS, 2016 - ZUS Annual Report 2016).

The e-tools used by ZUS to provide its services worth mentioning are as follows:

- Electronic Services Platform (PUE),

- e-contribution,

- E-ZLA,

- E-AKTA.

The most recognised service ZUS is associated with as an e-office is the Electronic Services Platform (PUE). Its users may set up their personal profiles enabling them to have an insight into information presenting their insurance status (Raport Roczny ZUS 2016). Since 2016 it has been possible to set up a PUE profile and log on to the portal using electronic banking. The service may be used by clients of the banks ZUS has concluded agreements with. Because ZUS information system is continuously updated, the list of forms and documents available via PUE is growing. Owing to this fact, PUE enables among other things servicing applications for Polish retirement pension, inability to work pension (Polish-English, Polish-French version); issuing an individual interpretation regarding public levies and social insurance or healthcare contributions; changing data regarding an address, surname/first name; payment of a benefit into a bank account or change of a bank account held by a person residing in Poland and abroad (Raport Roczny ZUS, 2016).

At the end of 2018, there were more than $2.72 \mathrm{~m}$ profiles on the PUE. Several roles may be attributed to one account on the ZUS PUE, clients may also authorise other persons to use their account, thus at the end of December 2018 there were accounts held by: the insured - 2,858,309, payers - 2,521,020, beneficiaries - 1,502,681, doctors - 124,695, court enforcement officers 2,239. In 2018 clients sent more than $15.2 \mathrm{~m}$ documents via ZUS PUE including: over $8.9 \mathrm{~m}$ electronic sick leave forms, over $4.7 \mathrm{~m}$ applications 
(most sent by court enforcement officers $-4.2 \mathrm{~m}$ and contribution payers - 427,000), nearly $1.6 \mathrm{~m}$ insurance documents from e-Płatnik (e-Payer) application. In 2018 there were on average 41,800 logins onto ZUS PUE every day as compared to 18,400,000 every day in 2017 (Raport Roczny ZUS, 2018). An overview of the functionality that is offered for PUE account holders depending on their assigned role is presented in the table.

The e-contribution project is aimed at contribution payers. Since January 2018 about $2.6 \mathrm{~m}$ entrepreneurs (contribution payers) have been making one bank transfer into an individual contribution account number (NRS). Each of them is given an individual contribution account number (NRS) into which they make payments towards all types of social insurance (and health insurance), without dividing the payment into subfunds. To make it easier for entrepreneurs to verify whether they are making their payment into an appropriate bank account, the last 10 digits of the NRS number are the same as their NIP (Tax Identification Number), which the entrepreneur used to register at ZUS, or when the tax identification number was not assigned, a payer's unique 10-digit number is used (ZUS dla biznesu, 2017). There is no need anymore to mark ZUS money transfers with two payer identifications (e.g. NIP and PESEL) or specify a month for which the contribution is made as the individual contribution account number enables identification of each transfer. No matter which contributions and in what amount a payer is obliged to pay, all levies are transferred into one account. ZUS in turn records such payments into funds: the Social Insurance Fund (where contributions to social insurance, pension insurance, sickness insurance, and work accident insurance), the National Health Fund, the Labour Fund, the Fund of Employee Guaranteed Benefits, and the Bridging Retirement Pension Fund. Also, the costs of reminders, enforcement costs and unpaid additional charges, if they are recorded on a payer's account, are cleared automatically. If in any of the funds there are any uncleared receivables for prior periods, then current payments are first recorded towards the oldest unpaid liabilities. Consequently, default interest does not accrue (Raport Roczny ZUS, 2018). The e-contribution programme has led to fewer mistakes in money transfers being made. In 2018, only 346 payments made to ZUS contained errors, that is on average 29 payments a month. That is $99.9 \%$ less than the year before when more than 271,000 payments were incorrectly marked. An incorrect payment made into NRS is automatically returned to the sender's bank account so that they may correct the mistake (Raport Roczny ZUS, 2018).
The e-ZLA project replaced a paper sick leave form, i.e. ZUS ZLA, with an electronic sick leave document. Since 1 December 2018 all doctors are obliged to issue sick leave documents in an electronic form. In Poland, 147,000 doctors and feldshers are authorised to issue sick leave documents. 117,000 of them have a doctor's profile on the ZUS Electronic Services Platform (PUE ZUS), which enables them to issue electronic sick leave documents. Only in December 2018 doctors issued over 2 million such documents (Raport Roczny ZUS, 2018). Issuing of an e-ZLA is faster than in the case of a paper sick leave form. A doctor or a medical assistant has access to data of the patient (the insured), their employers (contribution payers) and family members - if sick leave is issued in connection with care over them. After entering the patient's PESEL number, all other identification data is automatically completed by the system. Moreover, the system automatically verifies the date of the commencement of the incapacity period regarding the compliance with the rules for issuing sick leaves specified in legal regulations and with regard to the last issued sick leave.

Since 1 January 2019 amended regulations regarding the time for storing documents, employee records and their digitisation, i.e. the so-called e-archives, are in force. The act provides that employers shall be obliged to store employee records for 10 years and not 50 years, because ZUS will have all data needed to obtain benefits and specify their amounts. In monthly individual reports submitted by contribution payers, there are data needed to establish the pension or disability pension (including the income for a specific period). These data are saved by ZUS in the account of the insured person. As estimated, owing to digitisation the costs incurred by a company employing about 500 persons may decrease by as much as PLN 200,000 a year, taking into account the reduction in costs of labour, paper, printing, transportation, storing or of specialist equipment, e.g. armoured cabinets (gov.pl, e-acta, 2020).

Current information regarding benefits and changes in social insurance is uploaded by ZUS onto its website www.zus.pl. The website includes about 1,500 pages and is one of the largest public institution websites in Poland. In 2018 there were on average more than $1.4 \mathrm{~m}$ page views a month. The website complies with the WCAG 2.0 standards, i.e. standards of accessibility for people with disabilities (Raport Roczny ZUS, 2018). All payers may contact ZUS and obtain information on the institution's website and the Electronic Services Platform (www.zus.pl), in the Call Centre (22 5601600$)$, and via Skype (zus_centrum_obslugi_tel). Some of the information is available $24 / 7$ by means of an interactive voice response system (IVR). Around 
the clock, seven days a week payers may use 150 self-service points. Using them, we may file paper insurance documents, applications and letters, and we may also obtain a receipt of their submission (Raport Roczny ZUS, 2017).

All efforts taken by ZUS to achieve the status of a client-friendly, modern and innovative institution have been bringing results in recent years in form of the change in the way citizens perceive the institution. According to research conducted by CBOS and regarding "The assessment of operations of public institutions and the media", among central public institutions dealing with the day-to-day serving of clients, the Social Insurance Institution is ranked highest by the Poles (CBOS 2020). The social group which ranks the Social Insurance Institution the highest is those aged 55 and above, i.e. mostly pensioners. The high scores given by beneficiaries are the result of their regular contact with the Institution and services provided by ZUS employees. Surely, the higher scores of the Institution were also the effect of the introduction of services of a special pension consultant (ZUS.pl).

The results of the analysis of this parameter show the growing popularity of e-administration from 2017, as since this time the number of clients visiting client's service rooms has been declining. Nevertheless, the indicator remains high showing that ZUS clients are attached to the traditional form of contact. The difference in availability of electronic solutions and options a client had between 2016 and 2019 is enormous, but it brought only slightly more than a 2 million decrease in interest in direct service.

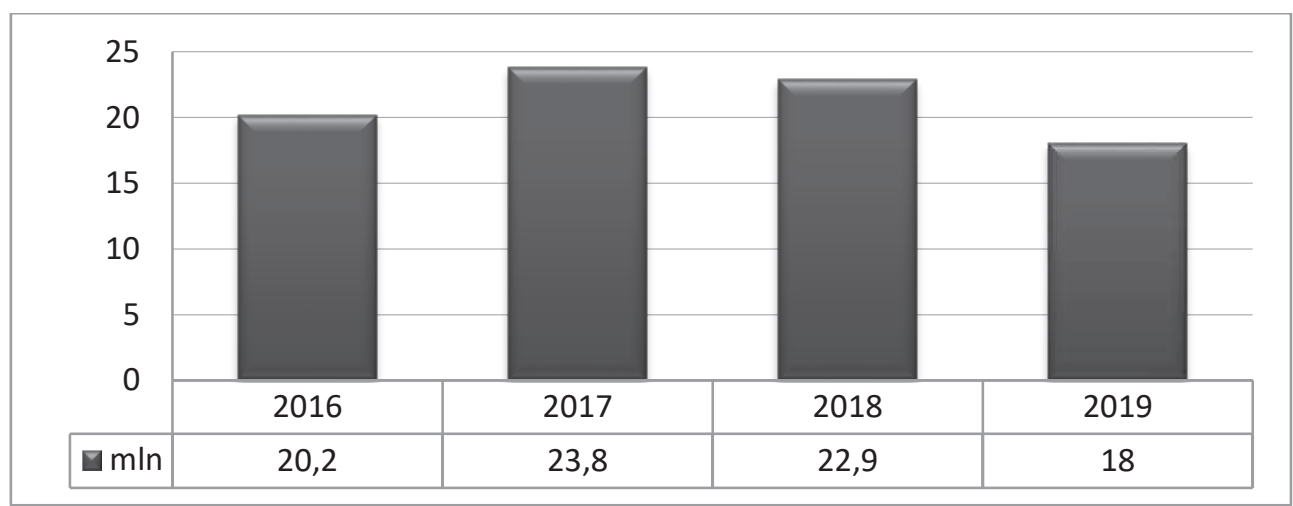

Figure 1. Persons visiting service rooms (in million)

Source: own elaboration based on Raport roczny ZUS, 2016

https://www.zus.pl/documents/10182/167526/Raport+roczny+ZUS+2016.pdf/74b11b94-eb9c-4d8e-bcae-1debe3cb8f81?version=1.0 [accessed: 10.08.2020], Raport roczny ZUS $2017 \mathrm{https}: / / \mathrm{www} . z$. pl/documents/10182/167526/Raport+roczny+ZUS+2017/12e2b5b7-1aaf4601-ba8a-f758cdb44bac?version=1.0 [accessed: 10.08.2020], Raport roczny ZUS 2018, https://www.zus.pl/documents/10182/167526/ Raport+roczny+2018.pdf/8fofbe93-1756-2477-25e3-7d08a9486556 [accessed: 10.08.2020], Sprawozdanie z działalności Zakładu Ubezpieczeń Społecznych za 2019 rok https://bip.zus.pl/documents/493361/494101/Sprawozdanie+z+działalności+ZUS+za+2019.pdf/ ed47ef58-7655-70b2-0eaf-5b7aab713042[accessed: 10.08.2020].

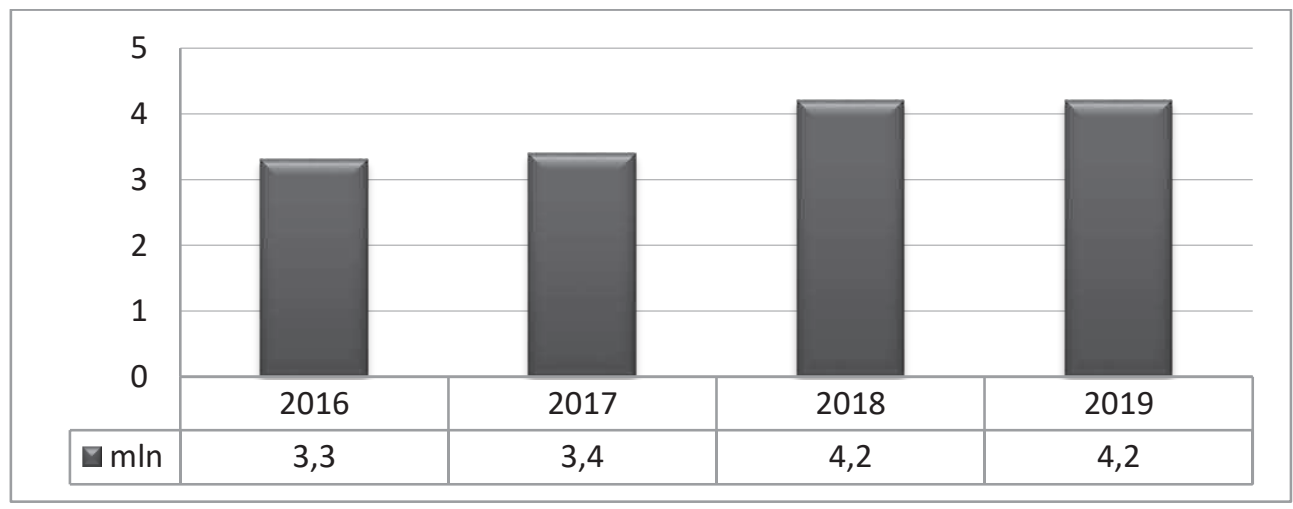

Figure 2. Contacts served by the Call Centre (million)

Source: own elaboration based on Raport roczny ZUS, 2016

https://www.zus.pl/documents/10182/167526/Raport+roczny+ZUS+2016.pdf/74b11b94-eb9c-4d8e-bcae-1debe3cb8f81?version=1.0 [accessed: 10.08.2020], Raport roczny ZUS 2017 https://www.zus.pl/documents/10182/167526/Raport+roczny+ZUS+2017/12e2b5b7-1aaf4601-ba8a-f758cdb44bac?version=1.0 [accessed: 10.08.2020], Raport roczny ZUS 2018, https://www.zus.pl/documents/10182/167526/R aport+roczny+2018.pdf/ 8f0fbe93-1756-2477-25e3-7d08a9486556 [accessed: 10.08.2020], Sprawozdanie z działalności Zakładu Ubezpieczeń Społecznych za 2019 rok https://bip.zus.pl/documents/493361/494101/Sprawozdanie+z+działalności+ZUS+za+2019.pdf/ed 47ef58-7655-70b2-0eaf-5b7aab713042[accessed: 10.08.2020]. 
The analysis of data regarding contacts with the Call Centre between 2016 and 2019 shows a growing interest in this specific electronic solution. Starting from 2016 when the number of calls was 3.3 million, this indicator has been increasing year to year since then. In 2019 it was 4.2 million contacts a year. It may be assumed that it is the fastest and the least problematic method of client's contact with the institution (apart from the waiting time to be connected). However, it should also be noted that options offered with this form of contact are limited. Data regarding contributions paid towards social insurance were analysed to examine the effect of the e-contribution on the efficiency of operations of the social insurance system. Paying all types of insurance with one money transfer, without the need for marking it with two multi-digit identifications is helpful both for clients and for ZUS. Figures for 2016-2019 show a gradual increase in the amount of paid-in contributions. In 2016 ZUS received in these payments PLN 153.2 bn, a year later PLN 166.6 bn, in 2018 PLN - 184.3 bn, and in 2019 PLN 198.3 bn. This was also the result of a linked to the functioning of e-contribution, a mass information campaign regarding payer's ZUS account balance (many persons learned about their outstanding payments), which has become an annual practice since 2018. This favourable trend in contribution payments is linked by analysts to the change in the method of clearing payments. Before 2018 an entrepreneur could have outstanding payments regarding periods going even several years back, and at the same time, they could be making payments allotted to currents months so that they remained insured. Starting from 1 January 2018 , to pay current contributions, all arrears must be settled.

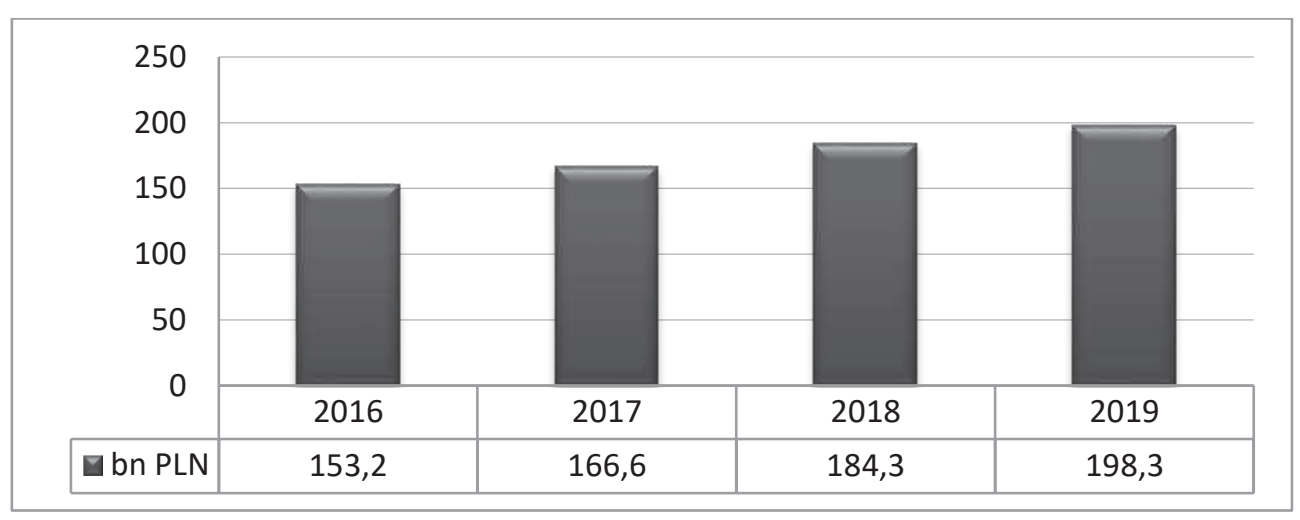

Figure 3. Contributions paid to ZUS towards social insurance (PLN bn)

Source: own elaboration based on Raport roczny ZUS $2016 \mathrm{https}: / /$ www.zus.pl/documents/10182/167526/Raport+roczny+ZUS+2 016.pdf/74b11b94-eb9c-4d8e-bcae-1debe3cb8f81?version=1.0 [accessed: 10.08.2020], Raport roczny ZUS 2017 https://www.zus.pl/ documents/10182/167526/Raport+roczny+ZUS+2017/12e2b5b7-1aaf-4601-ba8a-f758cdb44bac?version=1.0 [accessed: 10.08.2020], Raport roczny ZUS 2018, https://www.zus.pl/documents/10182/167526/Raport+roczny+2018.pdf/8fofbe93-1756-2477-25e3-7d08a9486556 [accessed: 10.08.2020], Sprawozdanie z działalności Zakładu Ubezpieczeń Społecznych za 2019 rok (Report on the operations of the Social Insurance Institution for 2019)https://bip.zus.pl/documents/493361/494101/Sprawozdanie+z+działalności+ZUS+za+2019.pdf/ed47ef58-765570b2-0eaf-5b7aab713042[accessed: 10.08.2020].

For ZUS, a scant number of incorrect payments is also a benefit and an improvement. Earlier, when payments had to be marked with two IDs, payers often made mistakes. Since every payer was given their own individual account number for payments, additionally ending with their NIP (tax identification number), errors have most often been generated by accounting offices providing services for various entities, and also by comprehensive payers. The results of the analysis of this indicator confirm the hypothesis that eservices affect the efficiency of functioning of the social insurance system.

To specify the level of knowledge and application of electronic services offered by ZUS, research was also conducted among the institution's clients.
Analysing answers given by respondents one may notice an upward trend regarding an interest in e-services in the analysed period. By far the majority of respondents noticed ZUS efforts aimed at the development of e-administration. Some new electronic solutions such as one individual bank account for all ZUS payments or e-ZLA are obligatory nowadays, which directly translates into their application and interest among clients. The majority of entrepreneurs express a positive opinion that one money transfer monthly instead of three transfers into three different accounts is a step forward in accordance with the trend for electronisation of communication between a citizen and public administration.

Among all the respondents, the vast majority, i.e. as many as $71 \%$, decided that in the analysed 
period ZUS made enormous progress in the implementation of e-services, at the same time becoming an institution more friendly to its clients, both currents ones and prospective ones. $21 \%$ expressed an opposite opinion, and $8 \%$ did not form any opinion.

Question 2 referred to knowledge of e-services provided by ZUS. Among all the respondents, eZLA service, i.e. electronic sick leave form, enjoyed the greatest popularity. $55 \%$ of respondents indicated this service as the best-known one. The introduction of e-ZLA affected the efficiency of the whole procedure of reporting incapacity due to sickness. An employer receives information about the sick leave just a moment after a doctor has issued it. The insured does need to submit to the employer proof that they are on sick leave, thus they do not run the risk that their benefit may be reduced due to late submission of the sick leave document. The ZUS website was another e-service that was used relatively most often by the respondents ( $44 \%$ of persons indicated this e-service). A wide range of practical information regarding social insurance, also many legal regulations and theoretical information, is a mine of knowledge for website users.

The next two services which were frequently used by the respondents are linked to PUE (the Electronic Services Platform). These are: the feature allowing a client to check the insured's account balance $(38 \%$ of respondents used this service in the analysed period) and to apply for and/or collect certificates (e.g. regarding employment periods in specified conditions or of specific character). This service was used by $36 \%$ of respondents.

A detailed breakdown of answers and possible variants of ZUS e-services which the analysed question referred to are presented in the chart below.

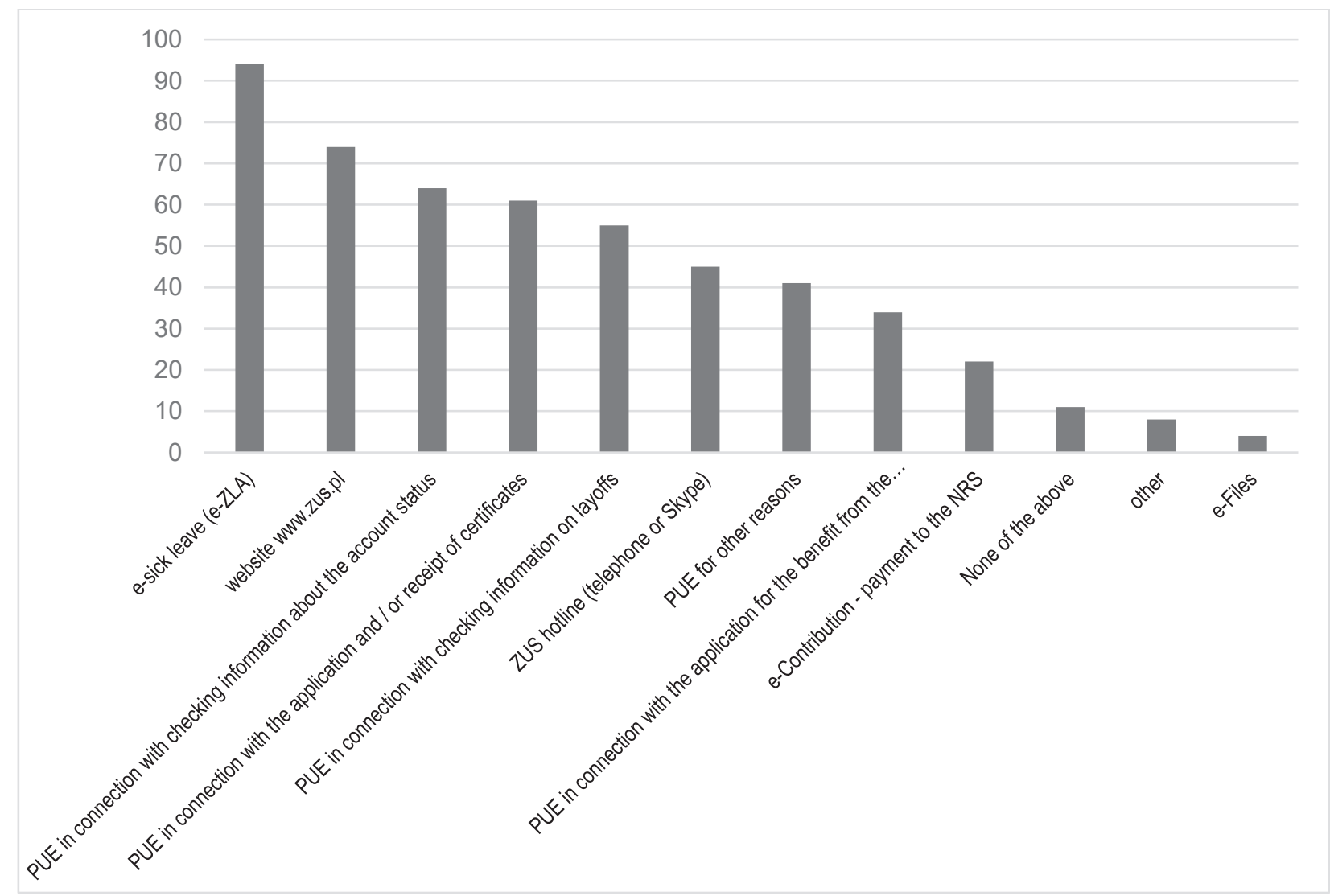

Figure 4. What digital facilities of ZUS have you come in contact with?

Source: own elaboration.

Collected data show that digital tools, which ZUS concentrated its efforts on in years 2016-2019, are used by clients. PUE is the most frequently used platform of ZUS e-services, which is a tool considerably facilitating the functioning of the social insurance system. Owing to its multi-functionality it is referred to as the e-office.

Question 3 was aimed at learning which forms of gaining knowledge: electronic or face-to-face is preferred by respondents. $42 \%$ of those surveyed 
strongly prefer the electronic form. $19 \%$ declare that they prefer to use on-line service; however, occasionally they decide to have personal contact and visit a ZUS branch. A similar percentage of respondents (18\%) prefer personal contact, and $6 \%$ definitely prefer to "visit" ZUS to use e-services. The respondents aged 18-45 show the largest interest in digital facilities. In this group, as many as $91 \%$ choose an e-service instead of a visit to a ZUS branch.

The last question referred to the opinion of whether or not e-services contribute to the higher efficiency of customer service ate ZUS and whether or not they constitute a system improvement. In this respect, $78 \%$ of those surveyed expressed an opinion that using digital tools, the introduction of eservices by ZUS institutions streamlined and facilitated customer service to a large extent. Persons aged 45 and below constituted $68 \%$ of those positively oriented toward e-services in ZUS. Thus, persons who actively and rather frequently use the Internet and new technological developments in their operations.

\section{Summary and conclusions}

The electronisation of contacts between a citizen and public administration is a dynamically developing area. This is encouraged by new technological developments, broadband and widely available internet, and currently, also the pandemic situation caused by COVID-19.

In our contemporary reality, digitisation and development of electronic channels as well as ensuring an appropriate level of maturity of services provided via these channels are the directions adapted in most sectors of the economy. Thus, it is important that the administration keeps up with development and, against widely held views, it opens up to clients and their needs.

As a result of the conducted analysis, we may draw the following conclusions regarding e-services offered by the Social Insurance Institution:

1. Owing to the introduction of the e-contribution, the Social Insurance Institution tightened the payment collection system, whereas payers do not accumulate debt in form of interest after a new method of clearing payments was introduced.

2. The Electronic Services Platform (ZUS PUE) is a tool readily used by the Social Insurance Institution's clients, and the number of persons having their profile on the Platform is continuously increasing.

3. Still a large number of ZUS clients is attached to the traditional, direct form of service.

4. The majority of ZUS clients claim that using electronic access channels is easy and it has sped up the customer service process considerably.

To use digital solutions offered by ZUS even more readily, clients need in the first place to be aware of their existence and to know what features they offer. PUE may serve as an example here as it offers a wide range of options and although it is frequently used, most clients have not discovered its entire functionality yet.

\section{References}

Agustí, C.M. (2011). The Regulation of Diffusion of Public Sector Information Via Electronic Means: Lessons from the Spanish Regidation, Government Information Quarterly, 28(2).

Batko, K., Bilewicz, G. (2013). E-usługi w biznesie i administracji publicznej [E-services in business and administration], Studia Ekonomiczne. Zeszyty Naukowe Uniwersytetu Ekonomicznego w Katowicach (136).

CBOS, Komunikat z badań oceny działalności instytucji publicznych [Results on research pertaining to activities of public institutions], https://www.cbos.pl/SPISKOM.POL/2020/K 038 20.PD (11.08.2020).

Dąbrowska, A., Janoś-Kreso, M., Wódkowski, A. (2009). E-usługi a społeczeństwo informacyjne [E-services and social information]. Difin, Warszawa.

Fils, R. (2009). E-usługi-definicja i przykłady [E-services - definitions and examples]. PARP, Warszawa.

Fleszer, D. (2014). Wokół problematyki e-administracji [E-administion in analysis], Roczniki Administracji i Prawa 14(1).

Gov.pl, E-akta, www.gov.pl/web/rozwoj/e-akta (13.08.2020).

Holgersson, J., Karlsson, F. (2014). Public e-service development: Understanding citizens' conditions for participation, Government Information Quarterly 31(3) https://www.diva-portal.org/ smash/get/diva2:737773/FULLTEXT01.pdf (4.11.2020).

Jastrzębska, K. (2018). Elektroniczna administracja jako narzędzie wdrażania zmian organizacyjnych [Electronic administation as a tool for implementing orgainisation change]. CeDeWu, Warszawa.

Kowalewski, M. (2019). Usługi teleinformatyczne administracji publiczne [Tele-info services and public administration], Oficyna Wydawnicza Politechniki Warszawskiej, Warszawa.

Kvasnicova, T., Kremenova, I., Fabus, J. (2016). From an Analysis of e-services Definitions and Classifications to the Proposal of New e-service Classification, Procedia Economics and Finance https://www.researchgate.net/publication/305396 364_From_an_Analysis_of_e-services_Definitions_and_Classifications_to_the_Proposal_of_ New_e-service_Classification (4.11.2020). 
Lindgren, I., Jansson, G. (2013). Electronic services in the public sector: A conceptual framework, Government Information Quarterly 30 https://isiarticles.com/bundles/Article/pre/pdf/917 9.pdf (4.11.2020).

Radu, A-M., Pólkowski, Z. (2014). Theoretical, technical and practical aspects of e-administration, Zeszyty Naukowe DWSPiT. Studia z Nauk Społecznych" (7), https://www. researchgate.net/publication/261712638_Theo retical_technical_and_practical_aspects_of_ e-administration (4.11.2020).

Sibiga, G. (2006), Podstawy prawne komunikacji elektronicznej w relacjach obywatel - organ administracji publicznej (od informacji do transakcji), Informacja prawna a prawa obywatela [Legal bases of electronic communication in relations between a citizen and a public administration body (from information to transaction), legal information and citizens' rights]. Warszawa.

Sofiarti, A., Analysing e-Administration in Developing Countries: Challeneges \& Best Practices https://www.academia.edu/10662081/Analysin g_e_Administration_in_Developing_Countries _Challenges_and_Best_Practices (4.11.2020).

Społeczna odpowiedzialność ZUS. Raport za $2018 \quad$ r., http://raportyspoleczne.pl/wpcontent/uploads/

raports/3d72478514d26dff9689a92cbd16913b .pdf (12.08.2020).

Śliwiński, M. (2008). Modele biznesowe e-usług [Business models for e-services], Polska Agencja Rozwoju Przedsiębiorczości, Warszawa.

Wojsyk, K. (2014). Wystąpienie podczas XXII Forum Informatyki w Administracji [Speech at the 22nd IT Forum in Administration]. Centrum Projektów Informatycznych, Sobienie Jeziory.
Wolny, R. (2013). Rynek e-usług w Polsce - funkcjonowanie i kierunki rozwoju [The e-services market in Poland - functioning and developmental directions]. Wyd. Uniwersytetu Ekonomicznego, Katowice

ZUS dla biznesu, 10-11/2017, https://www.zus.pl/ documents/10182/678129/ZUS+dla+biznesu 10-11_2017.pdf/12dacd29-7690-4171-9ce3$5865 \mathrm{~d} 35 \mathrm{f} 1 \mathrm{~d} 5 \mathrm{~b}(11.08 .2020)$

ZUS, Opinia o ZUS najlepsza w historii, https://www.zus.pl/o-zus/aktualnosci//publisher/aktualnosc/0/opinia-o-zusnajlepsza-w-historii/2506105 (26.08.2020)

ZUS, Raport Roczny ZUS 2016, https://www.zus. pl/documents/10182/167526/Raport+roczny+ ZUS+2016.pdf/74b11b94-eb9c-4d8e-bcae1debe3cb8f81?version=1.0 (10.08.2020).

ZUS, Raport roczny ZUS 2017, https://www.zus. pl/documents/10182/167526/Raport+roczny+Z US+2017/12e2b5b7-1aaf-4601-ba8af758cdb44bac?version=1.0 (10.08.2020).

ZUS, Raport roczny ZUS 2018, https://www.zus. pl/documents/10182/167526/Raport+roczny+2 018.pdf/8f0fbe93-1756-2477-25e37d08a9486556 [data dostępu: 11.08.2020].

ZUS, Raport Roczny ZUS 2018, https://www.zus. pl/documents/10182/167526/Raport+roczny+2 018.pdf/8fOfbe93-1756-2477-25e37d08a9486556 (11.08.2020). 